\title{
The Effectiveness of an ESP Training Program in Developing some Computer-Based Language Instruction Skills among Secondary Stage EFL Teachers
}

\author{
Hanan Wahid Hassan El-Morsi
}

\begin{abstract}
The current study investigated the effectiveness of an ESP program in developing some suggested computer-based language instructional skills among secondary stage EFL teachers. Forty teachers were randomly chosen and assigned as participants in the training sessions held during the academic year 2017-2018. The study adopted the quasi-experimental design and qualitative interpretation. For carrying out the experimental treatment, the researcher designed and developed the following instruments to be administered as pre-post applications: (1) a questionnaire for identifying teachers' attitudes towards integrating technology in EFL instruction and (2) an Ed Tech knowledge test for investigating the effectiveness of the program in developing the identified computer-based instructional skills. T-test was employed to measure the differences between the means of the experimental group's performances in the pre-post treatments. The findings indicated that there were statistically significant differences in the mean scores of the pre-post applications of the instruments. These positive results have made it clear that the program was successful in developing the teachers' computer-based instructional skills and was of a great help in integrating information and communication technology (ICT) in teaching EFL. Consequently, this success led to the rejection of the null hypotheses and accepting the alternative ones.
\end{abstract}

Key Words: English for Specific Purposes (ESP), EFL computer-based instruction, EFL teacher technological training, technological training programs

\section{Introduction}

The $21^{\text {st }}$ century confronts the individuals with new choices, opportunities and challenges due to today's indispensible presence of technology into all fields of life such as business administration and education (Plante \& Beattie, 2004). Traditional teaching and learning paradigms have been greatly

shaken by the impact of the integration of Information and Communication Technologies (ICT) into the educational practices. At the same time, teachers and trainers are confronted by challenges which range from the acquisition of skills and literacy in the usage of ICT to the delivery of 
the necessary technological techniques and applications which, which in return, will lead students to become knowledge creators and users (Albirini, 2006). In other words, one of the greatest challenges to be overcome on the way to the $21^{\text {st }}$ century is to enable teachers and students to achieve competency and mastery on the use of technology for education (Johnson, 2000). It was stated by Pedersen \& Liu (2003) that the permeating presence of ICT in the field of teaching and learning EFL, allows unlimited access to information and a flexibility of time and space barriers. According to Johnson (2000), new challenges emerge together with new teaching and learning environments and instructional modalities. This implies that the profound integration of new technologies into teaching/learning EFL will require changes in teachers' attitudes and teaching paradigms (Plante \& Beattie, 2004).

\section{Review of Related Literature}

The interest of promoting Information and Communication Technology (ICT) as a platform for providing teachers and students with authentic opportunities for EFL teaching/learning has been stressed by Dede (2000) and Beckett et al. (2003). Since computer technology was introduced to the field of English language teaching/learning as CALL (Computer Assisted Language Learning), many advantages had been brought to both language teachers and learners (Pirani, 2004). More recently, the use of computer applications have presented additional benefits to the learning environment as they enable the integration of virtually unlimited multimedia learning materials from external sources into the curriculum and make them available to students at any location in the world, i.e. distance education where there is a technological device with Internet access (Plante $\&$ Beattie, 2004). As a matter of fact, computer technology can empower students' language learning because students can access different applications like the internet, emails, software games, speech programs, digital videos among others which give them the access to different authentic materials, sources and tools (Baylor \& Ritchie, 2002; Waxman et al., 2002). All these technological facilities will, in return, motivate language students to learn and use English in nonthreatening environments (Brown, 2001).

As for Kleiman (2001) it was stated that implementing technology in the English language classes can make students more interested about the subject, 
decreases learning time, and provides opportunities to learn in non-traditional ways. Also, it was concluded that technology has the capacity to afford opportunities for powerful teaching and learning (Hermans et al., 2008) and can impact students' positive learning as stated by (Cancannon et al., 2005). In addition, Mahdizadeh et al. (2008) asserted the fact that motivation is also affected by technology whereas Lim et al. (2003) and Claudia et al. (2004) thought that technology play a vital role in developing students' critical thinking and autonomy. According to Kleiman (2001), the application of computer technologies for teaching English provides a student-centred learning environment as it:

1. enables teachers to vary lesson presentation styles to motivate students of individual differences and varying interests,

2. provides learning opportunities outside the classroom and increases student interaction with the language,

3. enriches the styles of presentation and increases language retention, and

4. appeals to students as they are digital natives.

In addition, it is stated by Cuban et al. (2001) that the use of computer technology reduces teacher-centeredness and consequently, it is capable of reducing student language learning anxiety as it gives them the chance to practice the language comfortably without being embarrassed of making mistakes (Mahdizadeh et al., 2008).

Broadly speaking, students learn from computers when the computer assumes the role of a tutor for imparting and increasing basic knowledge and skills (Waxman et al., 2002). Also, students learn with computers when it serves as a facilitating tool to develop critical thinking skills, research skills, and enriching their creative imagination as stated by Ringstaff \& Kelley (2002) and Lim et al (2003). A significant amount of literature explored the potentials of computer technology with regards to teaching and learning languages more effectively (Hermans et al., 2008). Benson et al. (2011) and Bereiter (2002) asserted that the possibilities of computer technology could increase the language students' 1) self-esteem, 2) vocational preparedness, 3) language proficiency and 4) overall academic skills. Besides, hypermedia technology with its linking and interactive capabilities was proved to be highly effective in enhancing vocabulary learning (Bulger et al., 2008), and reading comprehension 
(Payne \& Witney, 2002). Today, many social networking applications such as Skype, Yahoo and Facebook allow this kind of meaningful communication and add an important dimension to authentic language exposure (Payne \& Witney, 2002).

The permeating presence of technology in the field of teaching and learning EFL allows unlimited access to information and a flexibility of time and space barriers (Kumar, 2016). Therefore, the $21^{\text {st }}$ century teachers and educators are supposed to be aware of the technological interactive capabilities, such as providing immediate feedback and increasing student autonomy, in addition to the capability of simulating realworld situations via audio and video applications (Hermans et al., 2008). Hence, the profound integration of new technologies into teaching/learning EFL will require changes in teachers' attitudes and teaching paradigms (Pedersen \& Liu, 2003). For example, teachers will have to adapt new methodological approaches, educational concepts and management aspects which will have to be enriched in technological environments. Consequently, flexible teaching and learning processes, interactive communication systems together with the emergence of alternative spaces to promote communication will generate new needs to be satisfied by EFL teachers (Payne, Witney, 2002; Plante \& Beattie, 2004).

Kleiman (2001) and Sczendeffy (2008) claimed that teachers' proper acquisition of pedagogical and technological skills besides proper competency will enable them to face the challenges imposed by the society of knowledge. In return, the EFL teachers will have the eagerness and ability to help their students become active to fulfill their learning needs and use the language in authentic situations (Muir-Herzig, 2004). Also, with the teachers' developed technological knowledge, more opportunities will be provided for students to participate and be involved in the learning process positively (Healey $\&$ Klinghammer, 2002). Due to the fact that teacher training is an essential key for reaching success in the acceptance and implementation of technology for teaching English as a foreign language (Prensky, 2001), the current study sought to design a specific training program to help the EFL teachers develop their computer-based instructional skills and make use of the proper technological applications and facilities for teaching the $21^{\text {st }}$ century students. 


\section{Statement of the Problem}

Secondary stage EFL teachers need to participate into a specific training program for developing their computer- based instructional skills which, in return, will lead to adopt positive attitudes towards integrating the technological applications in teaching English.

For solving the problem, the following main question was also raised:

To what extent can the suggested ESP training program be effective in developing some of the secondary stage EFL teachers' instructional skills?

The previously stated main question led to raising the following sub-questions:

1. What are the EFL teachers' perceptions and attitudes concerning the use of computer applications for teaching?

2. What are the identified computer-based instructional skills the EFL teachers need to acquire and master?

3. How can the program be effective in developing the EFL teachers' identified instructional skills?

\section{Hypotheses of the Study}

The current study tested the following hypotheses:

1. There is no statistically significant difference at 0.05 level between the mean scores of the experimental group's responses to the items of the pre-post applications of the questionnaire concerning teachers' attitudes towards applying technology for teaching EFL.

2. There is no statistically significant difference at 0.05 level between the performance of the experimental group on the pre-post applications of the Ed Tech knowledge test.

\section{Aims of the Study}

As it is important for EFL teachers to discover and activate the role of technology in their teaching process. Hence, the current study aimed at:

1. identifying some computerbased instructional skills needed for developing the participants' professional performance ,

2. designing an Ed Tech training program for developing the identified instructional skills, and

3. assessing the effectiveness of the suggested program in 
developing the identified skills among the chosen sample of the secondary stage EFL teachers.

\section{Significance of the Study}

It was hoped that the present study would contribute in:

1. assisting in designing appropriate technology-based training programs for developing EFL teachers' instructional skills,

2. sparking EFL teachers' interest in implementing computers and other technological devices into the designing of classroom content, i.e. project-based teaching and learning that will enhance students' motivation and learning products.

3. presenting a digital model for motivating EFL teachers to apply technology for a fruitful EFL instruction, and

4. paving the way for other researchers to investigate the effect of technology in developing other instructional skills among EFL teachers in the primary and preparatory stages.

\section{Limitations of the Study}

The study proceeded within the following limits:
1. identifying and developing some EFL computer-based instructional skills,

2. designing a training program for developing the identified instructional skills among EFL teachers of the secondary stage, and

3. administering the training program among secondary stage EFL teachers in Dikernis Educational Directorate, Dakahlia Governorate.

\section{Methodology}

The current study investigated the effectiveness of the training program in developing the EFL teachers' computer-based instructional skills besides adopting positive attitudes towards integrating the available technological facilities for teaching English in the secondary stage.

\section{Design}

The quasi experimental design was adopted for assessing the effectiveness of the suggested training program in developing the identified computer-based instructional skills. The treatment of the study depended on one experimental group. Forty secondary stage EFL teachers had the suggested training program which was designed after responding to the pre-applications 
of the questionnaire and the $\mathrm{Ed}$ Tech knowledge test.

\section{Participants}

Forty EFL teachers from Dikernis Educational Directorate, Dakahlyia Governorate exemplified one experimental group (see the participants' demographic features in Table 1). They were randomly chosen by the supervision staff as the training sessions were held in the EFL Technical Bureaus during the academic year 2017-2018.

Table 1. The Participants' Demographic Features

\begin{tabular}{|c|c|c|c|c|c|c|c|}
\hline \multicolumn{2}{|c|}{ Gender } & \multicolumn{3}{c|}{ Range of Age } & \multicolumn{3}{c|}{ Years of Experience } \\
\hline Male & Female & $\mathbf{4 0 - 4 5}$ & $\mathbf{4 5 - 5 0}$ & Over 50 & $\mathbf{1 0 - 1 5}$ & $\mathbf{1 5 - 2 0}$ & Over 20 \\
\hline 28 & 12 & 14 & 17 & 9 & 8 & 12 & 20 \\
\hline $70 \%$ & $30 \%$ & $35 \%$ & $42.5 \%$ & $22.5 \%$ & $20 \%$ & $30 \%$ & $50 \%$ \\
\hline
\end{tabular}

\section{Instruments}

To investigate the program's effectiveness in developing the teachers' identified computer-based instructional skills, the following instruments were designed and developed by the researcher:

1. A questionnaire for surveying the EFL teachers' perceptions, beliefs and attitudes towards applying technology for teaching/learning which was administered before and after the application of the program.

2. An Ed Tech Knowledge test for investigating the teachers' knowledge concerning the integration of computer applications in EFL instruction.

\section{Definition of terms}

\section{ESP (English for Specific} Purposes)
According to Dudley-Evans (1998), ESP is defined as the branch of English that meets the specific needs of students and is centered on the language appropriate to their career or field of study. It is also defined as the process of teaching a specific genre of mostly technical English for students with specific careers or fields of study (The Free Dictionary, 2012). Whereas Hortas (2008) perceived ESP courses as programs that focus on developing communicative competence in a specific field, such as aviation, business or technology.

Operationally, the term of ESP is defined as the sphere of the English language that is responsible for providing both of the technological terminology and knowledge necessary for handling the content of a specific course 
determined by the needs of a specific group of teachers or students.

\section{Computer-based Instruction}

This term refers to the use of computers in imparting training, monitoring trainee progress, providing feedback and assessing final results (The Free Dictionary, 2012). Computer-based instruction also refers to any curricula in which students interact with a computer as a key element of the learning process. It can be defined as a selflearning offline/online technique which involves interaction of the student with programmed instructional materials (WikiEducator, 2008). According to Blake (2001) and Cancannon et al., (2005), computer-based instruction is perceived as being the ability to provide immediate feedback on the learners' individual responses for identifying errors, being aware of misconceptions and motivating further learning.

Operationally,

Computerbased Instruction is defined as the large storage and calculating capacities of the computer that guarantee a great potential for its use in the classroom. It can give instructions to the students, call for responses, feedback the results, and modify further learning accordingly. The computer can also be used to measure each student's attainments, compare them with past performances, and then advise teachers on what parts of the curriculum they should follow next.

\section{Testing the Hypotheses}

The first hypothesis focused on investigating the effect of the training program on the teachers' attitudes towards applying technology in teaching EFL, the questionnaire was prepared, revised, elaborated and administered among the participants. The pre-administration of the questionnaire showed the teachers' sheer tendency to refuse the idea of applying technology and computer applications in the language instructional contexts. The participants' responses to the items of the questionnaire can be summarized as follows:

1. The participants were against the idea of using computers for instructional purposes as it makes them feel uncomfortable. As a result, they were also against Elearning and teaching. Besides, the participants did not believe that technology might have a significant role in improving their instructional skills, as seen in Figure 1. 


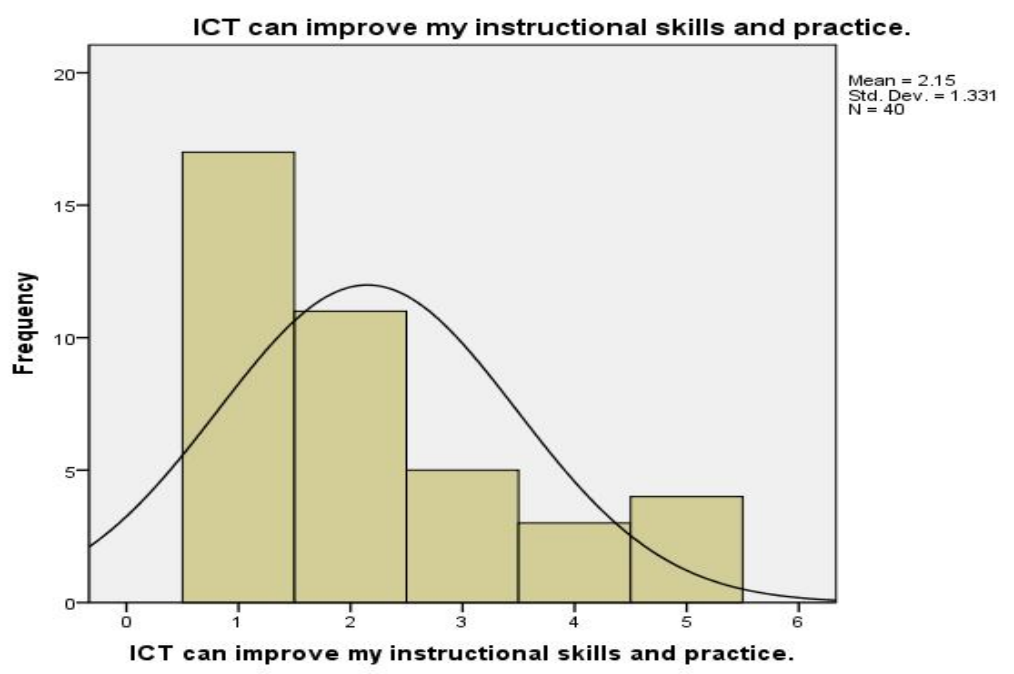

Figure 1. Teachers' attitude towards improving computer-based instructional skills

2. The teachers disregarded the possibility of using mobiles as instructional media besides denying the role of technology in enhancing their students' learning performance.

3. They strongly disagreed that computer technology is a vivid means for promoting students' interaction and communication skills. They forgot that the $21^{\text {st }}$ century students are interested in spending most of their time surfing the Net, chatting and sharing information with peers from other countries.

4. Thirty two teachers refused the possibility of creating virtual interactive classrooms via the Internet. As for saving time and effort when applying technology, 35 teachers denied the presence of these advantages.

5. Contrary to the call for ongoing professional development, the teachers refused that technology can help them acquire new technical and pedagogical skills. They also perceived technology as a threat to their instructional performance.

6. Although improvements in the classroom can be achieved via computer applications as technology appeals to the $21^{\text {st }}$ century students and can easily satisfy their needs, 29 teachers were completely against this idea.

7. According to 27 teachers, the presentation of a powerful environment in the language classes via ICT was impossible 
besides the refusal of applying technology in their classes despite the vast availability of the technological devices in the hands of both teachers and students.

8. The participants did not support the appropriateness of technology for creating and participating in meaningful activities. Consequently, the idea that technology provides a modern classroom atmosphere which surpasses the traditional environment in the classroom was refused.

The Results and Discussion of the

\section{Post Application of the}

\section{Questionnaire}

To investigate the extent to which the training program was successful in changing the participants' attitudes towards the integration of technology in the language classes, the questionnaire was administered in the end of the training sessions. The results showed the sheer switch in the teachers' attitudes towards the use of computers and the implementation of technology in their classes as follows:

1. For using technology in the language classes, 34 teachers supported teaching and learning the language via electronic media as seen in Figure 2.

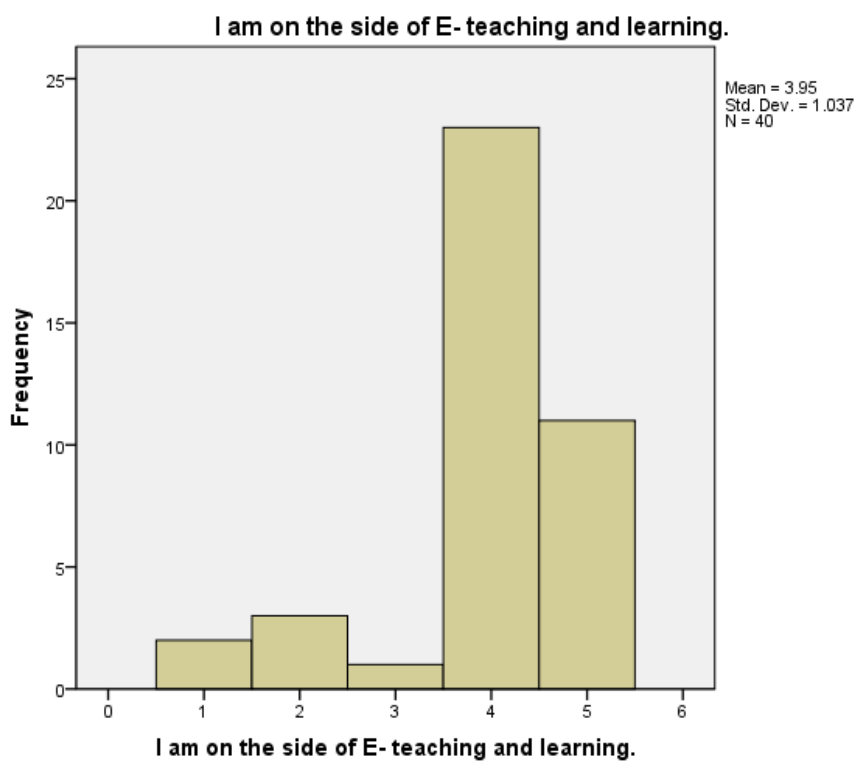

Figure 2. Teachers' enthusiastic tendency towards educational technology 
2.The teachers are now convinced that the implementation of ICT can improve their instructional skills especially after treating the issue of teaching via technological media. The use of mobile applications under the sponsorship of teachers is possible. Surprisingly, 31 teachers realized that their students' English skills can be promoted in case of integrating technology for teaching the language.

3. Previously, the trainees did not believe that interaction and communication could be successfully created via virtual classrooms. After the implementation of the program, their view highly shifted to adopt a positive attitude towards this facility as illustrated in Figure 3.

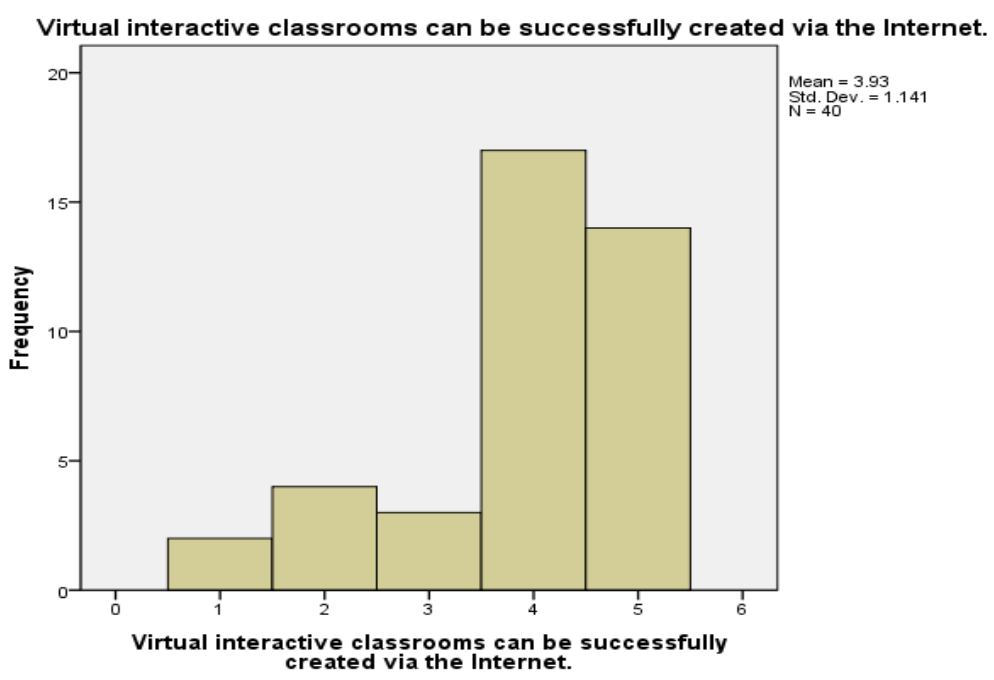

Figure 3. Teachers' positive belief of the Internet for teaching English

4. The idea of saving time and effort was previously refused when this questionnaire first administered. Now, 31 participants have a strong belief that technology can provide such advantages. Now, the teachers have awareness that integrating ICT in EFL instruction will equip them with new technical and professional skills.

5. Now, the participants believe that the use of technology for teaching English can make the environment in their classrooms more powerful as thirty teachers agreed. 
6. Previously, the participants did not ignore that the technological media are fast and efficient. After the implementation of the program, all of the teachers asserted these valuable advantages of technology.

7. At first, the teachers were conservatives and refused the good side of technology for teaching/learning purposes. Now, they are convinced that computer applications are good facilitators in today's modern classes. The participants realized that it is possible to use the Internet and the different available applications with their students inside and outside the classroom in case of setting the rules that may control this process.
8. The last four items in the questionnaire transformed the message that applying technology in the language classroom is appropriate for creating vivid learning activities. Hence, there was a clear tendency towards shifting from traditional to modern and technological classrooms. Due to this change, the teachers are supposed to be ready to consider their students' needs, interests and learning preferences.

To be more accurate, the Paired Samples T Test was used to estimate the t-value for the participants' responses in the prepost application of the questionnaire as seen in Table 2 . 
Table2. T-Value of the Participants' Responses in the Pre-Post Applications of the Questionnaire

\begin{tabular}{|c|c|c|c|c|c|c|c|}
\hline No & Statement & $\mathbf{N}$ & Mean & $\begin{array}{c}\text { Std. } \\
\text { Deviation }\end{array}$ & df & $\begin{array}{c}\text { T- } \\
\text { Value }\end{array}$ & $\begin{array}{l}\text { Sig. (2- } \\
\text { tailed) }\end{array}$ \\
\hline 1 & $\begin{array}{l}\text { The idea of using computers makes me } \\
\text { feel uncomfortable. }\end{array}$ & 40 & 2.150 & 1.657 & 39 & 8.206 & .000 \\
\hline 2 & $\begin{array}{l}\text { I am on the side of E- teaching and } \\
\text { learning. }\end{array}$ & 40 & 1.925 & 1.831 & 39 & 8.206 & .000 \\
\hline 3 & $\begin{array}{l}\text { I believe that ICT can really improve } \\
\text { my instructional skills and practice. }\end{array}$ & 40 & 1.825 & 1.752 & 39 & 6.586 & .000 \\
\hline 4 & $\begin{array}{l}\text { I enjoy using my modern mobile, as an } \\
\text { instructional tool, for teaching. }\end{array}$ & 40 & 1.650 & 1.545 & 39 & 6.754 & .000 \\
\hline 5 & $\begin{array}{l}\text { I believe that computer technology can } \\
\text { enhance students' learning performance. }\end{array}$ & 40 & 1.775 & 1.545 & 39 & 7.696 & .000 \\
\hline 6 & $\begin{array}{l}\text { I believe that computer technology is a } \\
\text { platform for promoting interaction and } \\
\text { communication among students. }\end{array}$ & 40 & 2.275 & 1.459 & 39 & 9.473 & .000 \\
\hline 7 & $\begin{array}{l}\text { Virtual interactive classrooms in } \\
\text { distance learning can be successfully } \\
\text { created via computer applications and } \\
\text { the Internet. }\end{array}$ & 40 & 2.200 & 1.471 & 39 & 9.458 & .000 \\
\hline 8 & $\begin{array}{l}\text { I think applying Information and } \\
\text { Communication Technology } \\
\text { saves time and effort in class. }\end{array}$ & 40 & 1.900 & 1.722 & 39 & 6.980 & .000 \\
\hline 9 & $\begin{array}{l}\text { I am aware that ICT can help me } \\
\text { acquire many new technical and } \\
\text { instructional skills. }\end{array}$ & 40 & 2.100 & 1.374 & 39 & 9.668 & .000 \\
\hline 10 & $\begin{array}{l}\text { I feel confident when it comes to } \\
\text { working with technology in class. }\end{array}$ & 40 & 1.350 & 1.703 & 39 & 5.014 & .000 \\
\hline 11 & $\begin{array}{l}\text { Classrooms would be better if } \\
\text { technology is integrated with teaching } \\
\text { EFL. }\end{array}$ & 40 & 1.925 & 1.639 & 39 & 7.428 & .000 \\
\hline 12 & $\begin{array}{l}\text { I would never use a computer in my } \\
\text { class even if it is available. }\end{array}$ & 40 & 2.100 & 1.374 & 39 & 9.668 & .000 \\
\hline 13 & $\begin{array}{l}\text { I believe that ICT can present a } \\
\text { powerful learning environment for } \\
\text { students in the classroom. }\end{array}$ & 40 & 2.175 & 1.615 & 39 & 8.515 & .000 \\
\hline 14 & $\begin{array}{l}\text { I am completely against applying } \\
\text { technology in teaching EFL. }\end{array}$ & 40 & 1.750 & 1.765 & 39 & 6.271 & .000 \\
\hline 15 & $\begin{array}{l}\text { I believe that computers are fast and } \\
\text { efficient means of getting information. }\end{array}$ & 40 & 2.025 & 1.593 & 39 & 8.039 & .000 \\
\hline 16 & $\begin{array}{l}\text { I perceive ICT as a means of doing } \\
\text { more harm than good. }\end{array}$ & 40 & 2.575 & 1.174 & 39 & 6.271 & .000 \\
\hline 17 & $\begin{array}{l}\text { Computer use is appropriate for many } \\
\text { language learning activities. }\end{array}$ & 40 & 1.625 & 1.564 & 39 & 6.572 & .000 \\
\hline 18 & $\begin{array}{l}\text { Applying technology in EFL classes } \\
\text { offers real advantages over traditional } \\
\text { methods of instruction. }\end{array}$ & 40 & 1.4 & 1.751 & 39 & 5.056 & .000 \\
\hline 19 & $\begin{array}{l}\text { Computer use best suits my students' } \\
\text { preferences and their level of computer } \\
\text { knowledge. }\end{array}$ & 40 & 1.825 & 1.338 & 39 & 8.629 & .000 \\
\hline 20 & $\begin{array}{l}\text { Applying technology in EFL instruction } \\
\text { should be a priority in education. }\end{array}$ & 40 & 1.600 & 1.809 & 39 & 5.594 & .000 \\
\hline
\end{tabular}


The t-values stated above indicate that there is a statistically significant difference between the mean scores of the participants' responses to the items of the prepost applications of the questionnaire perceptions and attitudes towards applying technology for teaching EFL. Hence, the first null hypothesis was rejected since the alternative hypothesis indicated the success of training program in changing the teachers' attitudes towards the use of technology for teaching English.

The Results and Discussion of the Quasi-Experimental Study

The current study aimed at determining the effectiveness of the proposed training program in developing the identified computerbased instructional skills among the EFL teachers in the secondary stage. Due to the teachers' technological profile, the Ed Tech knowledge test was prepared on an educational/technological basis. The revised and elaborated version of the test was administered among the 40 teachers before and after the application of the proposed program. The T-Test was employed to compare the means of the experimental group's scores on the pre-post application of the test. Below, the discussion of the correlation between the two applications of the test and the $\mathrm{t}$ value are presented in Table 3 and Table 4 in succession.

Table 3. The Correlation between the Teachers' Performances on the PrePost Application of the Test

\begin{tabular}{|c|c|c|c|c|c|c|c|}
\hline Test & $\mathbf{N}$ & Mean & $\begin{array}{c}\text { Std. } \\
\text { Deviation } \\
\end{array}$ & $\begin{array}{c}\text { Std. Error } \\
\text { Mean }\end{array}$ & \multirow{2}{*}{ Pair 1} & \multirow{2}{*}{ Correlation } & \multirow{2}{*}{ Sig. } \\
\hline Pre & 40 & 56.58 & 11.551 & 1.826 & & & \\
\hline Post & 40 & 106.63 & 7.791 & 1.232 & Pre \& Post & .544 & .000 \\
\hline
\end{tabular}

In the table above, the difference between the mean scores shows a high significant improvement of the teachers' performance and skills after the implementation of the program.
The correlation between the teachers' performance on the prepost administration of the test is considerably relative to the study since the significant correlation lies between $1-$ and $1+$. 
Table 4. Results of T- Test on the Pre-Post Administration of the Ed Tech Knowledge Test

\begin{tabular}{|c|c|c|c|c|c|c|c|c|}
\hline \multicolumn{9}{|c|}{ Paired Samples Test } \\
\hline \multirow{3}{*}{ Pair1 } & \multicolumn{5}{|c|}{ Paired Differences } & & & \multirow[b]{2}{*}{$\begin{array}{c}\text { Level of } \\
\text { Significance }\end{array}$} \\
\hline & & & & \multicolumn{2}{|c|}{$\begin{array}{c}95 \% \\
\text { Confidence } \\
\text { Interval of the } \\
\text { Difference } \\
\end{array}$} & & & \\
\hline & Mean & $\begin{array}{c}\text { Std. } \\
\text { Deviation }\end{array}$ & $\begin{array}{c}\text { Std. Error } \\
\text { Mean }\end{array}$ & Lower & Upper & t-Value & df & Sig. (2-tailed) \\
\hline $\begin{array}{l}\text { Pre - } \\
\text { Post }\end{array}$ & 50.05 & 9.8 & 1.55 & 46.9 & 53.18 & 32.27 & 39 & .05 \\
\hline
\end{tabular}

From the table above, it can be concluded that the second null hypothesis was also rejected to be replaced with the alternative one. The t-value for the pre-post administration of the Ed Tech Knowledge Test is 32.18. This indicates a statistically significant difference at .05 (two-tailed test). The results shown in the table above indicated that the program was effective in developing the identified computer-based instructional skills among the EFL teachers. In addition, the program was successful in shifting the teachers' perceptions, beliefs and attitudes towards integrating technology in EFL teaching from being extremely negative to extremely positive.

\section{Positive Outputs of the Study}

The results provided by both the quantitative and qualitative analysis of the obtained data have revealed the aspects which are related to the technological competences for English teachers and the training needs they actually needed before taking part in the training program. The teachers' positive participation in the training sessions has helped in finding more exact and detailed perceptions of the factors that can help them implement technology into their teaching practices successfully. Also, the barriers that may prevent the teachers from using technology and computer-based applications in a normal way have become clear. Examples of the positive outputs are presented below:

1. The training program was effective in developing identified computer-based instructional skills.

2. The training program was also effective in helping the teachers acquire positive attitudes towards integrating technology in EFL instruction. 
3. Some social media networks were utilized for launching professional educational groups, such as "Pioneers" on Facebook.

4. Educational channels were launched on YouTube and gained high applause from supervisors, teachers and students.

5. The participants have enthusiastic readiness for producing computer-based materials and designing appropriate activities for satisfying their students' interests.

6. The new perspectives of teaching English such as computer-mediated communication, connectivism,

blended learning and flipped classrooms have been added to the teachers' knowledge for enhancing students' computer-based learning.

7. The participants, now, have the confidence to search for and prepare authentic teaching materials suiting their students' needs and challenging their technological skills.

8. The participants have the ability to use Office 365 for preparing and sharing electronic tests online.

\section{Conclusion}

The current study provided indicative results that the participants showed positive attitudes and willingness to integrate computer-based applications for EFL teaching/learning purposes. As stated by Chen (2008), motivation is an important factor for teachers to be digital and meet the requirements of the $21^{\text {st }}$ century besides the provision of a userfriendly technological infrastructure. In this respect, the participants are aware of their new roles as innovative guides and facilitators who are to provide interactive and up-to-date materials for their students and to maximize student-student and teacher-student interaction.

\section{Recommendations}

Based on the results and conclusions of the present study, the following recommendations are offered:

1. Ongoing training of EFL teachers for blending technology and EFL instruction is crucially needed.

2. Training teachers to design computerized games and activities suiting the conditions in their classes is highly recommended. 
3. It is necessary to providing the school library and knowledge rooms with e- language books and stories relevant to the students' age, maturity, needs and interests to encourage them to build up positive attitudes towards learning the language via technology.

4. The professional training plans have to blend the technological knowledge with the pedagogical knowledge for their use, such as the creation and organization of CMC activities, and the evaluation of students' learning performance.

5. The need to set clear strategies and flexibility to develop the contents of the training programs related to integrating technology in teaching English.

6. Providing teachers with sources and e-activities which would allow them to successfully integrate technology into their teaching practices.

7. Stressing the importance of using ICT as a pedagogical tool in improving the quality of teaching.

8. Teachers' training needs have to be prior to the design, creation and implementation of teacher professional training programs.

\section{References}

Albirini, A. (2006). Teachers' attitudes toward information and communication technologies: The case of Syrian EFL teachers. Computers \& Education, 47, 373-398.

Baylor, A.L., \& Ritchie, D. (2002). What factors facilitate teacher skill, teacher morale, and perceived student learning in technology-using classrooms? Computers \& Education, 39, 395-414.

Beckett, E., Wetzel, K., Chishlom, I., Zambo, R., Buss, R., Padgett, H., Williams, M. \& Odom, M. (2003). Supporting technology integration in $\mathrm{K}-8$ multicultural classroom through professional development. Techtrends for Leaders in Education and Training, 47(5), 14-17.

Benson, V., Anderson, D. \& Ooms, A. (2011). Educators' perceptions, attitudes and practices: blended learning in business and management education, Research in Learning Technology, 19 (2), 143-154.

Bereiter, C. (2002). Education and Mind in the Knowledge Age. 
Mahwah, NJ: Lawrence Erlbaum.

Blake, R. (2001). What language professionals need to know about technology. ADFL Bulletin, 32, 93-99.

Brown, H. D. (2001). Teaching by Principles: An Interactive Approach to Language Pedagogy. Second Edition. New York: Pearson Education.

Cancannon, F., Flynn, A. \& Campbell, M. (2005). What Campus-based Students Think about the Quality and Benefits E-Learning? British Journal of Educational Technology, 36 (3), 501-512. Available at: http://dx:doi.org/10.1111/j.1467 -8535.00482.X.

Chen, Y. L. (2008a). A mixedmethod study of EFL teachers' Internet use in language instruction. Teaching and Teacher Education, 24 10151028.

Claudia, M., Steil, A. \& Todesco, J. (2004). Factors influencing the adoption of the Internet as a teaching tool at foreign language schools. Computers \& Education, 42 (4), 353-374.

Cuban, L., Kirkpatrick, H., \& Peck, C. (2001). High access and low use of technologies in high school classrooms: explaining an apparent paradox. American
Educational Research Journal, 38(4), 813-834.

Dede, C. (2000). Emerging influences of information technology on school curriculum. Journal of Curriculum Studies, 32(2), 281303.

Dudley-Evans, T. (1998). Developments in English for Specific Purposes: A multidisciplinary approach. Cambridge University Press.

Healey, D.D. \& Klinghammer, S. J. (2002). Constructing Meaning with Computers. TESOL Journal, 11(3), P. 3.

Hermans, R., Tondeur, J., Van Break, J. \& Valke, M. (2008). The impact of primary school teachers' educational beliefs on the classroom use of computers. Computer \& Education, 51 (4), 1499-1509. Available at:

http://dx.doi.org110.1016/j.comped u.2008.02.001.

Hortas, Jan D. (2008). English for Specific Puropses. Available at: http://studyusa.com/English/arti cles/esp.asp

Johnson, K.A. (2000). A Report of the Heritage Center of Data Analysis-DO Computers in the Classroom Boost Academic Achievement? Washington, DC: The Heritage Foundation. 
Kleiman, G. (2001). Myths and realities about technology in $K$ 12 schools. Leadership and the New Technology, 14. Retrieved August 27, 2005, from http://www2.edc.org/LNT/news Issue14/feature1.htm

Kumar, R. (2016). How the digital era is breaking learning barriers. Last updated, August 12, 2016. Available at: https://www.indiatoday.in/educ ation-

today/featurephilia/story/digital -learning-334807-2016-08-12.

Lim, C. P., Teo, Y.H., Wong, P., Khine, M. S., Chai, C.S. \& Divaharan, S. (2003). Creating a Conductive Learning Environment for the Effective Integration of ICT: Classroom Management Issues. Journal of Interactive Learning Research, 14 (4), 405-423.

Mahdizadeh, H., Biemans, H. \& Mulder, M. (2008). Determining Factors of the Use of E-Learning Environments by University Teachers.

Computers \& Education, 51 (1), 142-154. Available at: http://dx.doi.org/10.1016/j.com pedu.2007.04.004.

Muir-Herzig, R. G. (2004). Technology and its Impact in the Classroom. Computers \& Education, 42 (2): 111-131.
Payne, S. \& Witney, P. J. (2002). Developing Oral Proficiency through Synchronous CMC: Output, Working Memory and Inter-language Development. CALICO Journal, 20 (1), 7-32.

Pedersen, S. \& Liu, M. (2003). Teachers' beliefs about issues in the implementation of a student-centered learning environment. Education Technology Research \& Development, 51 (2), 57-76.

Prensky, M. (2001). Digital natives, digital immigrants. On the Horizon, 9(5), 16.

Pirani, J. (2004). Supporting elearning in higher education. Educause Center for Applied Research. Available at: www.educause.edu/ecar/.

Plante, J. \& Beattie, D. (2004, June). Connectivity and ICT integration in Canadian elementary and secondary schools: First results from the information and communication technologies in school survey, 2003- 2004. Ottawa, Canada: Statistics Canada.

Ringstaff, C. \& Kelley, L. (2002). The Learning Return on Our Educational Technology Investment. San Francisco, CA: WestEd.

Sczendeffy, John D. (2008). A Practical Guide to Using Computers in Language 
Teaching. Ann Arbor: The University of Michigan Press.

The Free Dictionary (2012). Computer Literacy. By Farlex, Inc. Available at: http://www.thefreedictionary.co $\underline{\mathrm{m}}$

Waxman, H. C., Connell, M. L. \& Gray, J. (2002). A Quantitative Synthesis of Recent Research on the Effects of Teaching and Learning with Technology on Student Outcomes. Naperville, IL: North Central Regional Educational Laboratory.

WikiEducator (2008). Computerbased Instruction. Available at:

http://wikieducator.org/Computer Assisted_Instuction_(CAI). 